\title{
Effect of metal additives on the physico-chemical characteristics of activated carbon exemplified by benzene and acetic acid adsorption
}

\author{
Hung-Lung Chiang ${ }^{\mathrm{a}}$, C.P. Huang ${ }^{\mathrm{b}, *}$, P.C. Chiang ${ }^{\mathrm{c}}$, J.H. You ${ }^{\mathrm{d}}$ \\ ${ }^{a}$ Department of Environmental Engineering, Fooyin Institute of Technology, Kaoshiung, Hsien, 831, Taiwan \\ ${ }^{\mathrm{b}}$ Department of Civil and Environmental Engineering, University of Delaware, Newark, DE 19716, USA \\ ${ }^{\mathrm{c}}$ Graduate Institute of Environmental Engineering, National Taiwan University, Taipei, Taiwan \\ ${ }^{\mathrm{d}}$ Department of Chemical Engineering, Chang-Gung College of Medicine and Technology, Tao-Yuan, Taiwan
}

Received 6 August 1998; accepted 30 April 1999

\begin{abstract}
The effects of treatment with inorganic salts exemplified by $\mathrm{Mg}\left(\mathrm{NO}_{3}\right)_{2}$ or $\mathrm{Ba}\left(\mathrm{NO}_{3}\right)_{2}$ on the physical-chemical characteristics of activated carbon were studied. Results indicate that the pore volume remains relatively unchanged upon salt treatment when the pore diameter ranges between $7 \AA$ and $20 \AA$. Significant variation in pore volume was observed when pore diameter is less than $7 \AA$; generally, the pore volume of $\mathrm{AC}$ is greater than $\mathrm{AC}-\mathrm{Ba}$ and $\mathrm{AC}-\mathrm{Mg}$. Major oxygen functional groups such as hydroxyl group for $\mathrm{AC}$, carboxyl group for $\mathrm{AC}-\mathrm{Ba}$, and hydroxyl and carbonyl groups for $\mathrm{AC}-\mathrm{Mg}$ were created. Regenerated at a temperature of $400^{\circ} \mathrm{C}$, creates more pore volume especially when treated with $\mathrm{Mg}\left(\mathrm{NO}_{3}\right)_{2}$ with an increase of $13.0 \%$. The regenerated $\mathrm{AC}-\mathrm{Mg}$ exhibits the greatest acetic acid adsorption capacity among all activated carbons studies. (C) 1999 Elsevier Science Ltd. All rights reserved.
\end{abstract}

Keywords: A. Activated carbon; D. Porosity, Surface areas

\section{Introduction}

Activated carbon is an effective adsorbent for volatile organic compounds (VOCs) and odors [1-4]. The adsorption of polar and non-polar compounds, on activated carbon is a non-selective process [1-4]. The spent activated carbon can be regenerated by thermal desorption. The organic solvent desorbed could be recovered by condensation or distillation. The exhaust gas from desorption can also be treated by various methods such as incineration [1-4].

In this investigation, metal salts were used as additives to modify the surface of activated carbon for the purpose of removing VOCs or odor pollutants at low concentration from air. This is done by hot air treatment as a means to oxidize the adsorbed VOCs. The presence of metals on the activated carbon surface could reduce the regeneration temperature and enhance the regeneration efficiency.

Many factors can effect the adsorption capacity of an

*Corresponding author. activated carbon. These include the surface characteristics, the chemistry of the adsorbate and the ambient condition $[5,6]$. In general, the larger the specific surface area, the greater the adsorption capacity. The specific surface area of commercial activated carbon is usually between 500 and $1300 \mathrm{~m}^{2} / \mathrm{g}$. Pore size distribution is determined by the composition of the activated carbon, the degree of activation, and the frequency of regeneration. The pore size distribution of an activated carbon greatly affects the capacity and rate of adsorption. Dubinin $[7,8]$ has differentiated pore size into four classes: micropores $(<0.6-0.7$ $\mathrm{nm}$ ), super micropores (between 0.6-0.7 and 1.5-1.6 nm), mesopore (between 1.5-1.6 nm and 100-200 nm), and macropore ( $>100-200 \mathrm{~nm})$. Urano and coworker [9] have showed that the adsorption capacity is proportional to the cumulative micropore volume (Note: Urano defined micropore size as those smaller than $32 \AA$ ).

The activated carbon surface has free and active charges. The charges can bind atoms and molecules, and change the surface characteristics of an activated carbon. When a large number of metal ions or oxygen functional groups are 
present on the activated carbon surface, the surface charge distribution will not be uniform. It has been reported that physico-chemical treatments can modify the activated carbon surface and its VOCs adsorption capacity.

Huston et al. [10] have showed that the adsorption of $\mathrm{MnO}_{2}$ onto the activated carbon surface enhances the adsorption capacity of water vapor. Stoecki [11] and Werner [12] have demonstrated that the water vapor adsorbed on the surface can influence the adsorption capacity of VOCs. Hiroshi [13] and Hahn [14] have studied the effect of acid and base treatment on the distribution of oxygen functional group and the VOCs adsorption characteristics. Swiatkowski et al. $[15,16]$ have treated activated carbon with $\mathrm{O}_{3}, \mathrm{H}_{2} \mathrm{O}_{2}$ and $\mathrm{H}_{2} \mathrm{SO}_{4}$ and reported that there are formation of oxygen functional groups on the activated carbon surface. As a result, the VOC's adsorption capacity of the treated activated carbon increases. The surface functional group plays an important role on the physico-chemical characteristics (such as dampness, catalytic effect and electrical properties) of activated carbon. Donnet et al. has classified the functional group into three clusters: acid, base and neutral [17]. The acid groups are carboxyl group (-COOH), hydroxyl group $(-\mathrm{OH})$, and carbonyl group $(-\mathrm{C}=\mathrm{O})$. The base group is chomene $\left(-\mathrm{CH}_{2}\right.$ or $-\mathrm{CHR}$ group), which can react with a strong acid and oxygen. The neutral neutral group is quinone-type carbonyl group [18].

\section{Experimentals}

\subsection{Adsorbents and adsorbates}

An activated carbon $(8 \times 30$ mesh $)$ provided by Kowa Cosmos Company, Japan, was selected for this research. Before experiments, the activated carbon was stored in an oven at $105^{\circ} \mathrm{C}$ for $48 \mathrm{~h}$. One kilogram of the activated carbon was added to 21 of $2 \mathrm{~N} \mathrm{Ba}\left(\mathrm{NO}_{3}\right)_{2}$ or $\mathrm{Mg}\left(\mathrm{NO}_{3}\right)_{2}$ solution and mixed vigorously with a rotator for $24 \mathrm{~h}$. The activated carbon was then separated from the solution, filtered, dried at room temperature, and then placed in a vacuum oven at $105^{\circ} \mathrm{C}$ for $24 \mathrm{~h}$. The temperature was then decreases to $30^{\circ} \mathrm{C}$ and the activated carbon was purged with nitrogen gas for $3 \mathrm{~h}$. Benzene and acetate were chosen as adsorbates as they are common industrial solvents. The concentration of adsorbates ranged between 700 and 2500 ppm.

\subsection{Adsorbents characterization}

The physical characteristics of the activated carbon including BET specific surface area, micropore area, micropore volume, and pore size distribution were determined using an ASAP 2000 micropore analyzer (Micromeritrics Inc., USA). The nitrogen adsorption was carried out at $77 \mathrm{~K}$. A photomicrography of the activated carbon surface was obtained by scanning electron microscope (SEM, Hitachi S-2400, Japan).

The nitrogen, carbon, hydrogen, and oxygen contents of the activated carbon were analyzed using an element analyzer (Heraeus CHN-O Rapid Element Analyzer, USA). Sulfur and chloride were detected with another element analyzer (Tacussel Coulomax 78) and sulfanilic acid and 1-chloro-2,4-dinitrobenzene as standards. However ICP-AES analysis of the activated carbon surface revealed no sulfur element. This same element analyzer was also used to detect the content of $\mathrm{Mg}$ and $\mathrm{Ba}$. The relative reference standard for ICP-AES was NBS-SRM1648. For the sake of quality assurance and quality control, duplicated analysis was conducted on five samples.

Analysis of oxygen functional groups on the activated carbon was done following the Bohem's titration method [9]. Place treated activated carbon in a vacuum oven $\left(10^{-2}-10^{-3} \mathrm{mmHg}, 105^{\circ} \mathrm{C}\right)$ for $24 \mathrm{~h}$. Weigh out $5 \mathrm{~g}$ of activated carbon. Prepare $\mathrm{NaOH}, \mathrm{NaHCO}_{3}$ and $\mathrm{Na}_{2} \mathrm{CO}_{3}$ solutions $(0.1 \mathrm{~N})$. Add $25 \mathrm{ml}$ of $0.1 \mathrm{~N}$ alkali solution and the pre-weighted activated carbon sample into a series of test tubes. The tubes are then placed in a vibrator and mixed at $100 \mathrm{rpm}$, and $25^{\circ} \mathrm{C}$ for $24 \mathrm{~h}$. Draw $5 \mathrm{ml}$ of the supernatant from the tubes for titration with $0.1 \mathrm{~N} \mathrm{HCl}$ solution. Calculate the concentration of various functional groups accordingly.

Table 1

Physical characteristics of $\mathrm{AC}, \mathrm{AC}-\mathrm{Ba}$ and $\mathrm{AC}-\mathrm{Mg}$

\begin{tabular}{lllll}
\hline Adsorbents & $\begin{array}{l}\text { BET surface } \\
\text { area }\left(\mathrm{m}^{2} / \mathrm{g}\right)\end{array}$ & $\begin{array}{l}\text { Micropore } \\
\text { area }\left(\mathrm{m}^{2} / \mathrm{g}\right)\end{array}$ & $\begin{array}{l}\text { Micropore } \\
\text { volume }(\mathrm{cc} / \mathrm{g})\end{array}$ & $\begin{array}{l}\text { Pore } \\
\text { diameter }(\AA)\end{array}$ \\
\hline $\mathrm{AC}$ & $776 \pm 28^{\mathrm{a}, \mathrm{b}, \mathrm{c}}$ & $664 \pm 26$ & $0.304 \pm 0.003$ & $14.91 \pm 0.02$ \\
& $(0 \%)$ & $(0 \%)$ & $0 \%)$ & $10 \%)$ \\
$\mathrm{AC}-\mathrm{Ba}$ & $668 \pm 32$ & $561 \pm 35$ & $0.268 \pm 0.006$ & $(-7.4 \%)$ \\
$\mathrm{AC}-\mathrm{Mg}$ & $(-13.9 \%)$ & $(-12.9 \%)$ & $0.276 \pm 0.003$ & $14.66 \pm 0.03$ \\
& $677 \pm 25$ & $581 \pm 21$ & $(-9.21 \%)$ & $(-16.8 \%)$ \\
\hline
\end{tabular}

\footnotetext{
${ }^{\mathrm{a}}$ Standard deviation.

${ }^{\mathrm{b}}$ Sample number: 5 .

${ }^{\mathrm{c}}$ The number value in parentheses denotes the variance of impregnated activated carbon.
} 


\subsection{Sorption experiments}

Place diffusion tubes filled with liquid benzene or acetic acid inside a temperature control tank to generate the VOCs. The temperature controller was maintained at less than $\pm 0.5^{\circ} \mathrm{C}$. Determine the concentrations of VOCs in the nitrogen stream by gas chromatography equipped with a flame ionization detector (HP, Model 5890 II).

Dry the activated carbon adsorbent in a vacuum oven (for $24 \mathrm{~h}$ at $105^{\circ} \mathrm{C}$ and $10^{-2}$ to $10^{-3} \mathrm{mmHg}$ ). Place $20 \mathrm{~g}$ of the activated carbon sample into a column (diameter of 2.5 $\mathrm{cm}$ ) and maintain the temperature at $30 \pm 0.5^{\circ} \mathrm{C}$ with a water bath. Purge the nitrogen gas at a rate of $21 / \mathrm{min}$ through the VOCs generator as to facilitate the transport of acetic acid and/or benzene vapor into the activated carbon column. The concentration of the adsorbates are analyzed by gas chromatography (HP-5890 GC). When the adsorption bed reaches the breakthrough, gas samples are taken at an interval of 5 to $10 \mathrm{~min}$ to monitor the residual VOCs concentration in the adsorption zone.

For regeneration, place five grams of the saturated activated carbon into the desorption tube through which a nitrogen gas was being purged at a flow rate of $21 / \mathrm{min}$ for $30 \mathrm{~min}$. The desorption temperatures were 30, 100, 200, 300 , and $400^{\circ} \mathrm{C}$, respectively. The regenerated adsorbents were analyzed for physico-chemical characteristics and VOCs adsorption capacity according to procedures described above.

\section{Results and conclusions}

\subsection{Physico-chemical characteristics analysis}

Table 1 shows specific surface area, micropore area, micropore volume, and pore diameter of the activated carbon. The specific surface area of AC (untreated), AC$\mathrm{Ba}\left(\mathrm{Ba}\left(\mathrm{NO}_{3}\right)_{2}\right.$ treated $)$ and $\mathrm{AC}-\mathrm{Mg}\left(\mathrm{Mg}\left(\mathrm{NO}_{3}\right)_{2}\right.$ treated $)$ are 776,668 and $677 \mathrm{~m}^{2} / \mathrm{g}$, respectively. The BET surface area decreases by $13.9 \%$ and $12.8 \%$ for $\mathrm{AC}-\mathrm{Ba}$ and $\mathrm{AC}-\mathrm{Mg}$ respectively compared to the untreated AC. The micropore area decreases from $644 \mathrm{~m}^{2} / \mathrm{g}$ for AC to 561 $\mathrm{m}^{2} / \mathrm{g}$ for $\mathrm{AC}-\mathrm{Ba}$ and $581 \mathrm{~m}^{2} / \mathrm{g}$ for $\mathrm{AC}-\mathrm{Mg}$. This is a decrease of $12.9 \%$ and $9.8 \%$ respectively for $\mathrm{AC}-\mathrm{Ba}$ and $\mathrm{AC}-\mathrm{Mg}$ with respect to the untreated $\mathrm{AC}$ sample. The micropore volume decreases from $0.304 \mathrm{~cm}^{3} / \mathrm{g}$ for AC to $0.268 \mathrm{~cm}^{3} / \mathrm{g}$ for $\mathrm{AC}-\mathrm{Ba}$ (a decrease of $11.8 \%$ ), and to $0.276 \mathrm{~cm}^{3} / \mathrm{g}$ for $\mathrm{AC}-\mathrm{Mg}$ (a decrease of $9.2 \%$ ). The pore diameter of the activated carbon remained relatively unchanged $14.8 \AA$ and $14.7 \AA$, versus at $14.9 \AA$ of the untreated $\mathrm{AC}$, for $\mathrm{AC}-\mathrm{Ba}$ and $\mathrm{AC}-\mathrm{Mg}$, respectively. This is an insignificant decrease of $0.7 \%$ for $\mathrm{AC}-\mathrm{Ba}$ and $1.7 \%$ for $\mathrm{AC}-\mathrm{Mg}$, individually with respect to the untreated $\mathrm{AC}$ samples. Results clearly indicate that $\mathrm{Ba}(\mathrm{II})$ and $\mathrm{Mg}(\mathrm{II})$ treatment of the activated carbon can decrease the specific (a) $\mathrm{AC}$

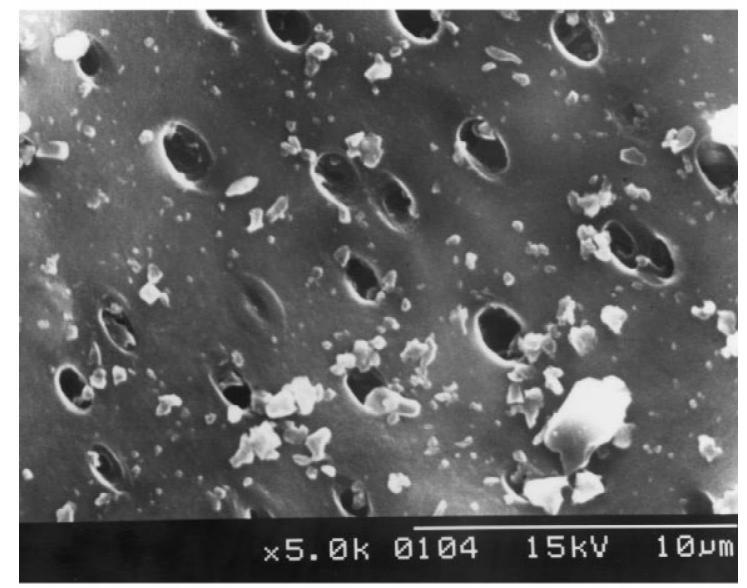

(b) $\mathrm{AC}-\mathrm{Ba}$

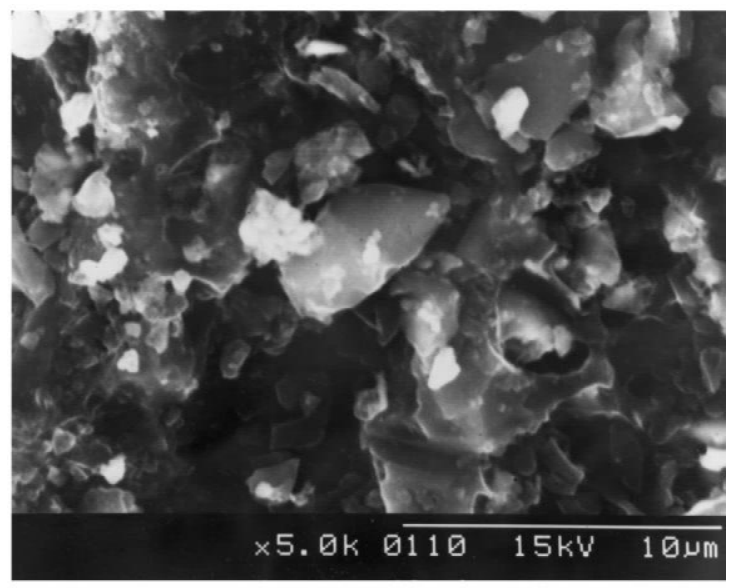

(c) $\mathrm{AC}-\mathrm{Mg}$

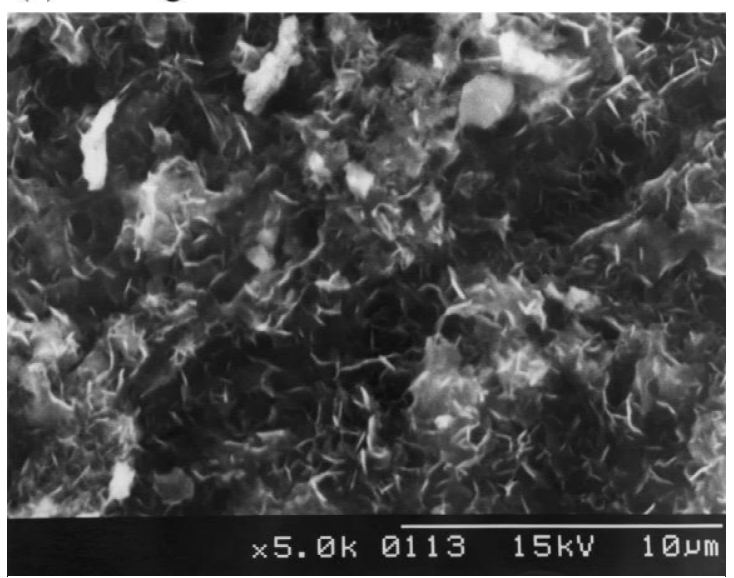

Fig. 1. SEM photomicrographs of (a) AC, (b) AC-Ba, (c) AC$\mathrm{Mg}$. Note that there are crystal formations upon salt treatment, pin shape with $\mathrm{AC}-\mathrm{Mg}$ and granular shape with $\mathrm{AC}-\mathrm{Ba}$. 
surface area, micropore volume, and pore diameter of the activated carbon.

Fig. 1 shows the SEM photos for these three activated carbon samples. Careful examination of the SEM pictures suggests that there are many pores in the grains of the activated carbon and the pore diameter is about $2 \mu \mathrm{m}$. SEM photos also reveals that there are salt crystals formed on the surface of $\mathrm{AC}-\mathrm{Ba}$ and $\mathrm{AC}-\mathrm{Mg}$. The irregular shape of the barium salt was formed on the $\mathrm{AC}-\mathrm{Ba}$ surface and a pin shape magnesium salt was formed on the $\mathrm{AC}-\mathrm{Mg}$ surface. Apparently, formation of crystal on the surface of $\mathrm{AC}-\mathrm{Ba}$ and $\mathrm{AC}-\mathrm{Mg}$ decreases the surface area and the pore volume of the impregnated activated carbon.

Fig. 2 demonstrates that the pore volume of $\mathrm{AC}$ is generally greater than those of the $\mathrm{AC}-\mathrm{Ba}$ and $\mathrm{AC}-\mathrm{Mg}$ in the pore diameter range of less than $20 \AA$. A significant variation of pore volume was observed on all activated carbon in the pore diameter range of less than $7 \AA$.

Table 2 shows results of the measurement of elements on the activated carbon surface. It shows that the elemental composition of $\mathrm{C}, \mathrm{N}$, and $\mathrm{O}$ on the activated carbon surface changes after the treatment with $\mathrm{Ba}\left(\mathrm{NO}_{3}\right)_{2}$ or $\mathrm{Mg}\left(\mathrm{NO}_{3}\right)_{2}$ solution. The nitrogen content is $0.22 \%, 0.94 \%$ and $0.52 \%$ for $\mathrm{AC}, \mathrm{AC}-\mathrm{Ba}$ and $\mathrm{AC}-\mathrm{Mg}$, respectively. The oxygen content increases from $10.8 \%$ for $\mathrm{AC}$ to $13.78 \%$ for $\mathrm{AC}-\mathrm{Ba}$ and $16.45 \%$ for $\mathrm{AC}-\mathrm{Mg}$. The results show that the activated carbon is impregnated by both $\mathrm{Ba}\left(\mathrm{NO}_{3}\right)_{2}$ and $\mathrm{Mg}\left(\mathrm{NO}_{3}\right)_{2}$ and that nitrate could be entrapped in the activated carbon which in turn will contribute nitrogen and oxygen to the activated carbon surface. The molar ratio of $\mathrm{C}: \mathrm{H}: \mathrm{O}: \mathrm{N}$ is $500: 115: 45: 1,100: 27: 13: 1$, and 167:55:27:1 for $\mathrm{AC}, \mathrm{AC}-\mathrm{Ba}$ and $\mathrm{AC}-\mathrm{Mg}$, respectively. This indicates that the surface polarity of the $\mathrm{AC}-\mathrm{Ba}$ and the $\mathrm{AC}-\mathrm{Mg}$ is greater than that of $\mathrm{AC}$. It is also noted that there is a slight loss of $\mathrm{C}$ during salt treatment.

Table 3 shows the results of oxygen functional groups. Results indicate that the oxygen functional group capacity is $0.290,0.343$, and $0.305 \mu \mathrm{eq} / \mathrm{g}$ for $\mathrm{AC}, \mathrm{AC}-\mathrm{Ba}$ and $\mathrm{AC}-\mathrm{Mg}$, respectively. This is a slight increase in oxygen functional group by $\mathrm{Ba}\left(\mathrm{NO}_{3}\right)_{2}$ and $\mathrm{Mg}\left(\mathrm{NO}_{3}\right)_{2}$ treatment. The predominant oxygen functional groups are the hydroxyl group $(-\mathrm{OH})$ on $\mathrm{AC}$, the carboxyl $\operatorname{group}(-\mathrm{COOH})$ on $\mathrm{AC}-\mathrm{Ba}$, and the hydroxyl $(-\mathrm{OH})$ and carbonyl $(-\mathrm{C}=$ $\mathrm{O})$ groups on $\mathrm{AC}-\mathrm{Mg}$. Since $\mathrm{Ba}^{2+}$ is a stronger oxidant than $\mathrm{Mg}^{2+}$ and the formation energy of carboxyl group is the greatest among all oxygen functional groups, it is

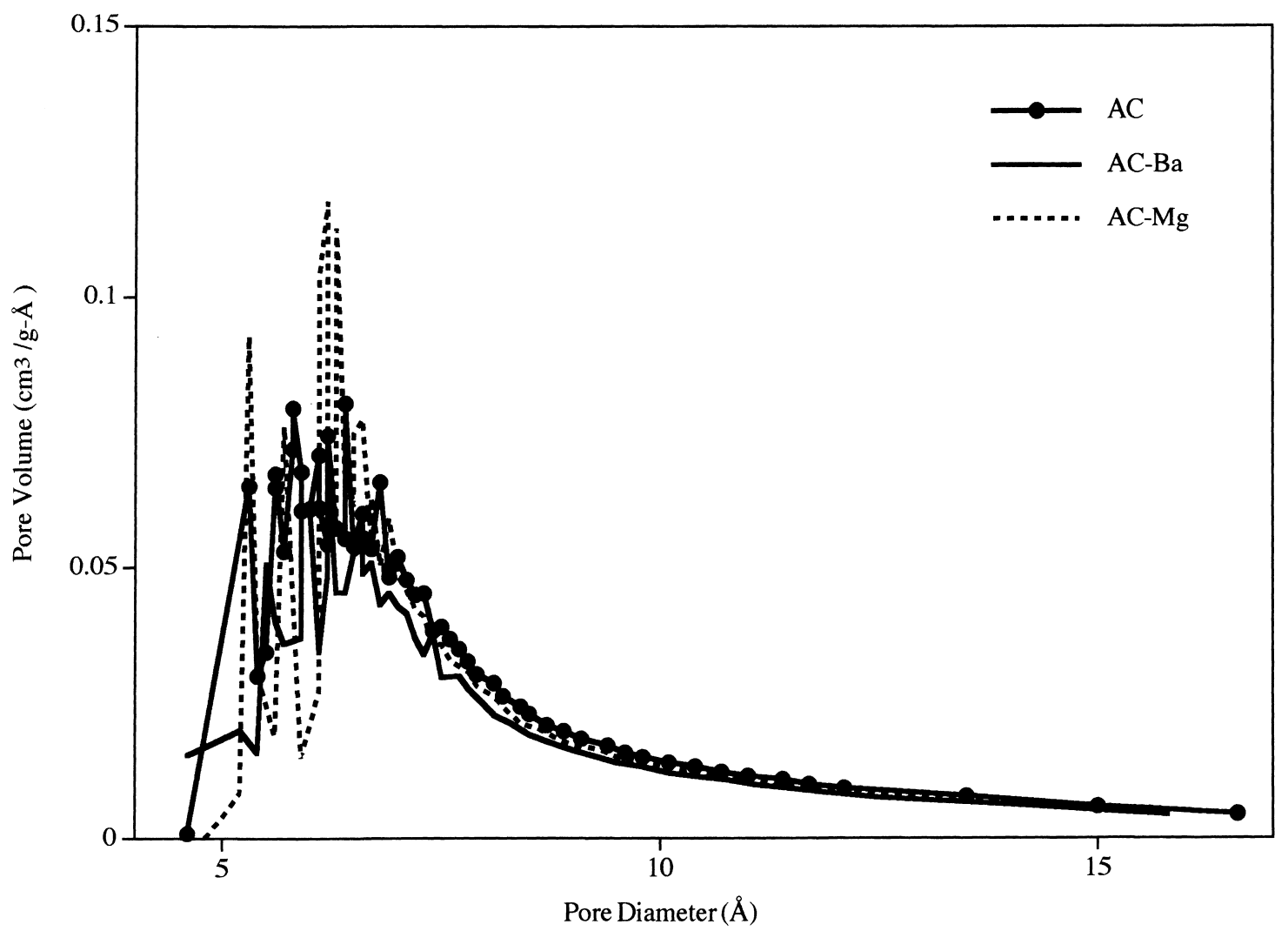

Fig. 2. Effect of metal additives on the distribution of micropore volume. Note that results are average of triplicates. 
Table 2

The compositions of $\mathrm{AC}, \mathrm{AC}-\mathrm{Ba}$ and $\mathrm{AC}-\mathrm{Mg}$ were analyzed by element analyzer and ICP-AES

\begin{tabular}{|c|c|c|c|c|c|c|c|c|c|}
\hline Adsorbents & $\begin{array}{l}\mathrm{N} \\
(\%)\end{array}$ & $\begin{array}{l}\mathrm{C} \\
(\%)\end{array}$ & $\begin{array}{l}\mathrm{H} \\
(\%)\end{array}$ & $\begin{array}{l}\mathrm{O} \\
(\%)\end{array}$ & $\begin{array}{l}\text { Molar ratio } \\
\text { C:H:O:N }\end{array}$ & $\begin{array}{l}\mathrm{Cl} \\
(\%)\end{array}$ & $\begin{array}{l}S \\
(\mu g / g)\end{array}$ & $\begin{array}{l}\mathrm{Ba} \\
(\mu \mathrm{g} / \mathrm{g})\end{array}$ & $\begin{array}{l}\mathrm{Mg} \\
(\mu \mathrm{g} / \mathrm{g})\end{array}$ \\
\hline$\overline{\mathrm{AC}}$ & $\begin{array}{l}0.22 \\
(0.27)\end{array}$ & $\begin{array}{l}86.52 \\
(0.02)\end{array}$ & $\begin{array}{l}1.69 \\
(1.8)\end{array}$ & $\begin{array}{l}10.87 \\
(0.37)\end{array}$ & $500: 115: 45: 1$ & $\mathrm{ND}^{\mathrm{abc}}$ & $\begin{array}{l}1602 \\
(6.7)\end{array}$ & $\begin{array}{l}7.60 \\
(5.8)\end{array}$ & $\begin{array}{l}405.22 \\
(4.5)\end{array}$ \\
\hline $\mathrm{AC}-\mathrm{Ba}$ & $\begin{array}{l}0.94 \\
(16)\end{array}$ & $\begin{array}{l}77.07 \\
(0.35)\end{array}$ & $\begin{array}{l}1.75 \\
(4.6)\end{array}$ & $\begin{array}{l}13.78 \\
(0.91)\end{array}$ & $100: 27: 13: 1$ & ND & $\begin{array}{l}1457 \\
(8.8)\end{array}$ & $\begin{array}{l}58325 \\
(2.3)\end{array}$ & $\begin{array}{l}285.59 \\
(5.8)\end{array}$ \\
\hline $\mathrm{AC}-\mathrm{Mg}$ & $\begin{array}{l}0.51 \\
(8.2)\end{array}$ & $\begin{array}{l}76.10 \\
(0.03)\end{array}$ & $\begin{array}{l}2.07 \\
(2.9)\end{array}$ & $\begin{array}{l}16.43 \\
(0.80)\end{array}$ & $167.55: 27: 1$ & ND & $\begin{array}{l}1514 \\
(4.3)\end{array}$ & $\begin{array}{l}14.38 \\
(4.5)\end{array}$ & $\begin{array}{l}53084 \\
(1.9)\end{array}$ \\
\hline
\end{tabular}

${ }^{\mathrm{a}} \mathrm{ND}$ : Detection value $<0.01 \%$.

${ }^{\mathrm{b}}$ The concentration of $\mathrm{N}, \mathrm{C}, \mathrm{H}, \mathrm{O}$, and $\mathrm{Cl}$ were analyzed by element analyzer and $\mathrm{S}, \mathrm{Ba}$, and $\mathrm{Mg}$ were analyzed by ICP-AES.

${ }^{\mathrm{c}}$ The numerical value in the parenthesis denotes the relative standard deviation based on two measurements.

possible that $\mathrm{Ba}^{2+}$ will oxidize the hydroxyl and carbonyl groups to form carboxyl group at greater extent than that of $\mathrm{Mg}^{2+}$.

\subsection{Adsorption capacity}

Fig. 3 shows the adsorption isotherms of benzene and acetic acid on activated carbon. The influent concentration of benzene varies from 784 to $2486 \mathrm{ppm}$ and the adsorption capacity of $\mathrm{AC}, \mathrm{AC}-\mathrm{Ba}$ and $\mathrm{AC}-\mathrm{Mg}$ ranges from 202 to $226 \mathrm{mg} / \mathrm{g}, 158$ to $181 \mathrm{mg} / \mathrm{g}$, and 168 to $189 \mathrm{mg} / \mathrm{g}$, respectively. The influent concentration of acetic acid ranges between 735 and $2352 \mathrm{ppm}$. The adsorption capacity is from 184 to $318 \mathrm{mg} / \mathrm{g}, 152$ to $267 \mathrm{mg} / \mathrm{g}$ and 169 to $269 \mathrm{mg} / \mathrm{g}$ for $\mathrm{AC}, \mathrm{AC}-\mathrm{Ba}$ and $\mathrm{AC}-\mathrm{Mg}$, respectively. The acetic acid adsorption capacity is greater than that of benzene. This can be attributed to the fact that the adsorption energy of acetic acid is smaller than that of benzene. Moreover with methyl and carboxyl as the major functional groups, acetic acid is a polar species whereas benzene is nonpolar. Therefore the acetic acid can be adsorbed onto both the non-polar and the polar site of adsorbent, whereas the benzene can only be adsorbed onto the non-polar sites. As a result, the acetic acid will be more adsorbable by the activated carbon than benzene.

\subsection{Length of unused bed and adsorption wave}

In order to further evaluate the VOC adsorption characteristics, activated carbon column experiments were conducted as to determine the dynamics of column utilization. The column was $2.5 \mathrm{~cm}$ in diameter and 7.5 to $8.0 \mathrm{~cm}$ long and packed with $20 \mathrm{~g}$ activated carbon which average diameter was $3 \mathrm{~mm}$. The concentrations of benzene in the gas flow (flow rate 2 1/min) were 2486, 2019 and 784 ppm and the concentrations of acetic acid were 2352, 1528, and $735 \mathrm{ppm}$. The adsorption temperature was maintained at $30 \pm 0.5^{\circ} \mathrm{C}$. Based on the effluent concentrations of VOC, i.e. benzene and acetic acid, the length of unused bed (LUB) and the length of adsorption zone $\left(\mathrm{L}_{\mathrm{z}}\right)$ can be calculated.

The length of unused bed is calculated as follow [19,20]:

$\mathrm{LUB}=\left(1-\frac{q}{q_{\mathrm{o}}}\right) \cdot L=\left(1-\frac{t^{\prime}}{t_{\mathrm{o}}}\right) \cdot L$

$t^{\prime}=\int_{0}^{t}\left(1-\frac{C}{C_{\mathrm{o}}}\right) \mathrm{d} t$

where $L$ : length of adsorption bed; $q_{0}$ : mass of adsorbate per mass of adsorbent at equilibrium; $q$ : mass of adsorbate per mass of adsorbent; $C_{\mathrm{o}}$ : influent adsorbate concen-

Table 3

The concentration of oxygen functional groups on $\mathrm{AC}, \mathrm{AC}-\mathrm{Ba}$ and $\mathrm{AC}-\mathrm{Mg}$

\begin{tabular}{lllll}
\hline Adsorbents & $\begin{array}{l}\text { Hydroxyl group } \\
(-\mathrm{OH})\end{array}$ & $\begin{array}{l}\text { Carbonyl group } \\
(-\mathrm{C}=\mathrm{O})\end{array}$ & $\begin{array}{l}\text { Hydroxyl group } \\
(-\mathrm{COOH})\end{array}$ & $\begin{array}{l}\text { Total oxygen } \\
\text { functional groups }\end{array}$ \\
\hline $\mathrm{AC}(\mu \mathrm{eq} / \mathrm{g})$ & $175 \pm 6^{\mathrm{ab}}$ & $55 \pm 9$ & $60 \pm 12$ & $290 \pm 7$ \\
$\mathrm{AC}\left(\mu \mathrm{eq} / 100 \mathrm{~m}^{2}\right)$ & $170 \pm 0.8$ & $8.3 \pm 1.2$ & $2.8 \pm 1.5$ & $28.1 \pm 0.9$ \\
$\mathrm{AC}-\mathrm{Ba}(\mu \mathrm{eq} / \mathrm{g})$ & $28 \pm 5$ & $78 \pm 4$ & $237 \pm 40$ & $343 \pm 10$ \\
$\mathrm{AC}-\mathrm{Ba}\left(\mu \mathrm{eq} / 100 \mathrm{~m}^{2}\right)$ & $3.0 \pm 0.7$ & $9.0 \pm 0.6$ & $27.4 \pm 6.0$ & $39.5 \pm 1.5$ \\
$\mathrm{AC}-\mathrm{Mg}(\mu \mathrm{eq} / \mathrm{g})$ & $127 \pm 4$ & $118 \pm 7$ & $60 \pm 7$ & $305 \pm 5$ \\
$\mathrm{AC}-\mathrm{Mg}\left(\mu \mathrm{eq} / 100 \mathrm{~m}^{2}\right)$ & $20.4 \pm 0.6$ & $12.8 \pm 1.0$ & $6.5 \pm 1.0$ & $39.7 \pm 0.7$ \\
\hline
\end{tabular}

\footnotetext{
${ }^{\mathrm{a}}$ Standard deviation.

${ }^{\mathrm{b}}$ Sample number: 5 .
} 
(a)Benzene

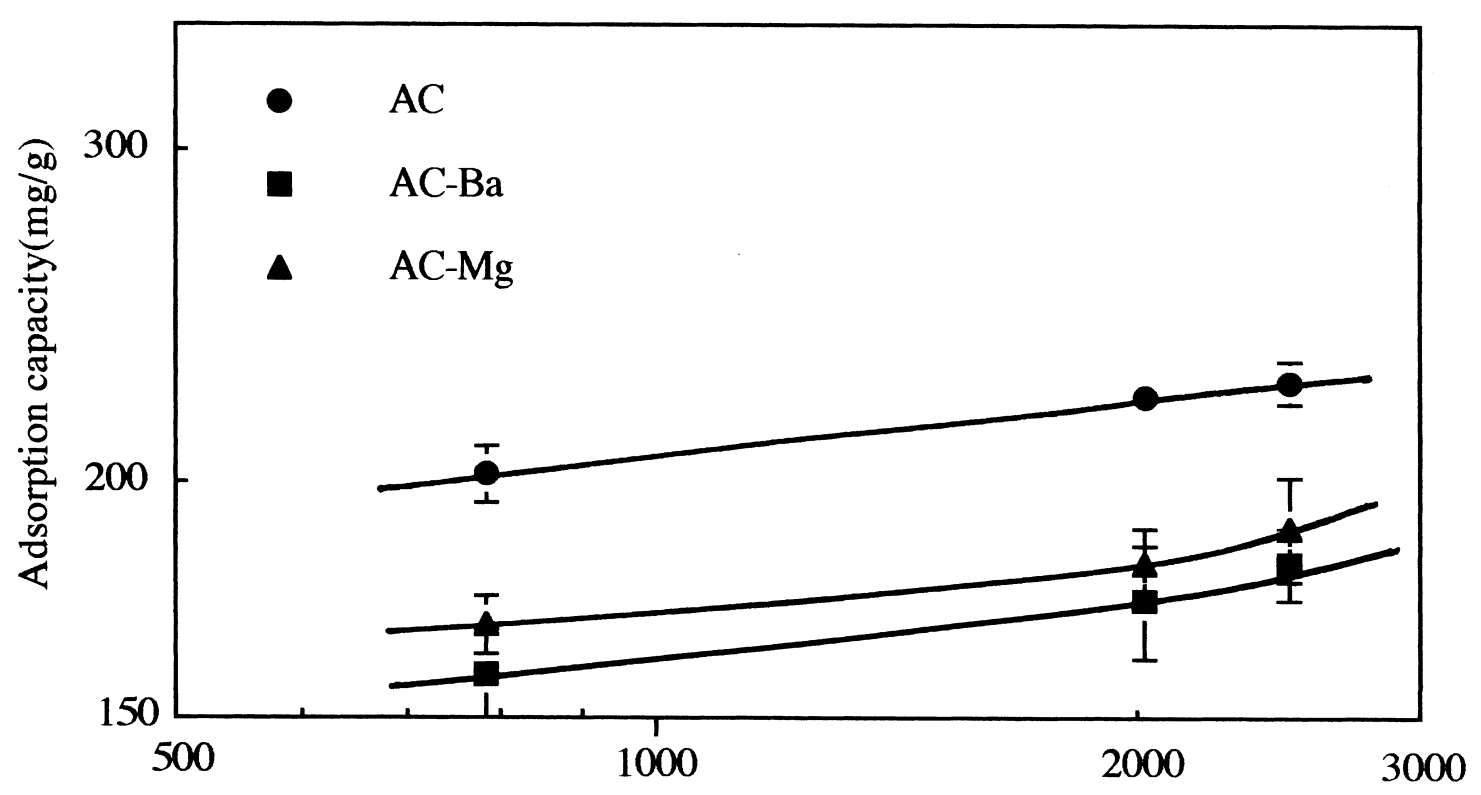

Concentration(ppm)

(b)Acetate

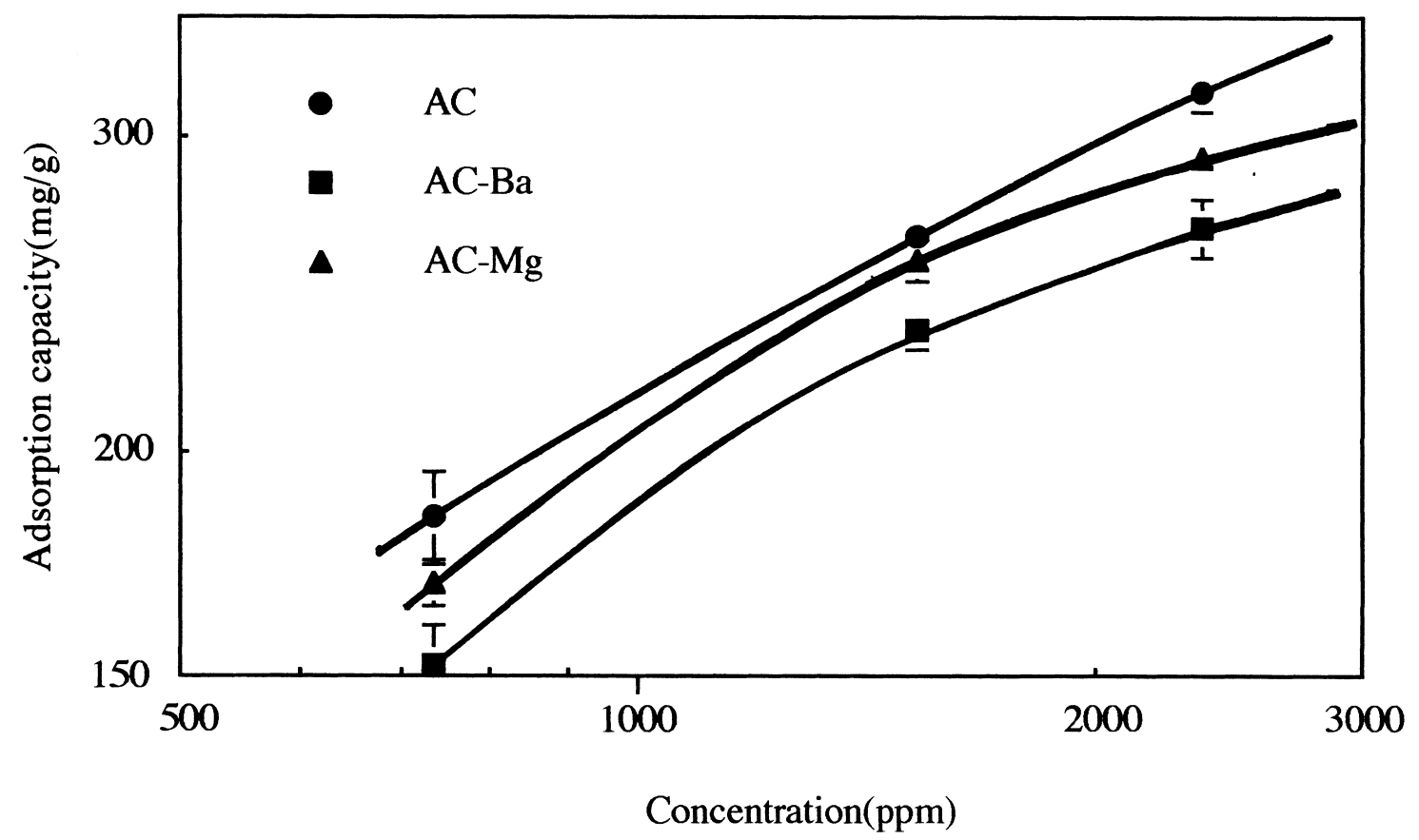

Fig. 3. Adsorption isotherm of benzene (a) and acetic acid (b) Experimental condition: temperature $=30 \pm 0.5^{\circ} \mathrm{C}$, influent adsorbed concentration $=784$ to $2486 \mathrm{ppm}$ (benzene) and from 735 to $2352 \mathrm{ppm}$ (acetic acid). 
tration; $C$ : outlet adsorbate concentration at time $t ; t_{\mathrm{o}}$ : time of adsorbent at equilibrium; $t^{\prime}$ : integrated time.

Table 4 shows the length of unused bed and adsorption wave. Under influent benzene concentrations between 784 and $2486 \mathrm{ppm}$, the length of unused bed (LUB) is between 1.27 and $1.61 \mathrm{~cm}, 1.48$ and $2.45 \mathrm{~cm}$ and 1.14 and 1.68 , for $\mathrm{AC}, \mathrm{AC}-\mathrm{Ba}$ and $\mathrm{AC}-\mathrm{Mg}$, respectively. Generally, the LUB of the $\mathrm{AC}-\mathrm{Ba}$ and the $\mathrm{AC}-\mathrm{Mg}$ activated carbons are greater than that of the untreated activated carbon with respect to benzene adsorption because $\mathrm{Ba}\left(\mathrm{NO}_{3}\right)_{2}$ and $\mathrm{Mg}\left(\mathrm{NO}_{3}\right)_{2}$ can precipitate into micropores during the drying process. As a result, the adsorption site is reduced. Moreover, reaction between nitrate ion and activated carbon will create oxygen functional groups and reduce the affinity between the benzene and the activated carbon.

Under influent acetic acid concentrations between 735 to $2352 \mathrm{ppm}$, the length of unused bed are between 1.81 to $3.75 \mathrm{~cm}, 1.94$ to $2.96 \mathrm{~cm}$, and 1.88 to $3.28 \mathrm{~cm}$ for $\mathrm{AC}$, $\mathrm{AC}-\mathrm{Ba}$ and $\mathrm{AC}-\mathrm{Mg}$, respectively. The LUB with respect to acetic acid adsorption appears to be less affected by salt treatment.

The length of adsorption zone $\left(L_{\mathrm{z}}\right)$ was calculated as follows $[19,20]$ :

$L_{\mathrm{z}}=L \cdot \frac{\left(t_{\mathrm{E}}-t_{\mathrm{B}}\right)}{\left(t_{\mathrm{E}}-t_{\mathrm{f}}\right)}$

$t_{\mathrm{f}}=(1-F) \cdot\left(t_{\mathrm{E}}-t_{\mathrm{B}}\right)$

$F=\int_{0}^{1}\left(1-\frac{C}{C_{\mathrm{o}}}\right) \mathrm{d}\left(\frac{t-t_{\mathrm{B}}}{t_{\mathrm{E}}-t_{\mathrm{B}}}\right)$

where $t_{\mathrm{E}}$ : time when $C$ reaches $0.95 C_{\mathrm{o}} ; t_{\mathrm{B}}$ : time when $C$ reaches $0.05 C_{\mathrm{o}} ; t_{\mathrm{f}}$ : formation time; $F$ : fraction of total utilization.

When the influent benzene concentrations are between 784 and $2486 \mathrm{ppm}$, the length of adsorption zone are between 1.41 and $1.88 \mathrm{~cm}, 1.65$ and $3.31 \mathrm{~cm}$, and 1.21 and $1.94 \mathrm{~cm}$ for $\mathrm{AC}, \mathrm{AC}-\mathrm{Ba}$ and $\mathrm{AC}-\mathrm{Mg}$, respectively. At an influent acetic acid concentration between 735 and 2352 ppm, the length of adsorption zone is between 2.21 and $6.30 \mathrm{~cm}, 2.28$ and $4.05 \mathrm{~cm}$ and 2.28 and 4.89 for $\mathrm{AC}$, $\mathrm{AC}-\mathrm{Ba}$ and $\mathrm{AC}-\mathrm{Mg}$, respectively. The length of adsorption zone of acetic acid is greater than that of benzene. This can be contributed in part to the fact that the acetate is more polar than benzene and that the affinity between acetic acid and activated carbon is stronger than that of benzene and active carbon.

\subsection{Desorption}

The adsorption efficiency of the adsorbent at various temperatures are showed in Fig. 4. In order to compare the desorption efficiency under the otherwise similar experimental condition, we selected two concentrations of benzene (784 and $2486 \mathrm{ppm}$ ) and acetic acid (735 and $2352 \mathrm{ppm})$ for desorption study. The desorption temperature increases from 30 to $400^{\circ} \mathrm{C}$ which results in an increasing benzene desorption efficiency from 17 to $95 \%$ for $\mathrm{AC}$, from 15 to $95 \%$ for $\mathrm{AC}-\mathrm{Ba}$ and from 18 to $97 \%$ for $\mathrm{AC}-\mathrm{Mg}$, individually. Generally, the greater the initial VOC concentration the greater is the desorption efficiency. The desorption efficiency of acetic acid are from 12 to $88 \%$ for AC, from 8 to $94 \%$ for $\mathrm{AC}-\mathrm{Ba}$ and from 20 to $97 \%$ for $\mathrm{AC}-\mathrm{Mg}$ when the desorption temperature increases from 30 to $400^{\circ} \mathrm{C}$. The desorption efficiency of impregnated activated carbons ( $\mathrm{AC}-\mathrm{Ba}$ and $\mathrm{AC}-\mathrm{Mg}$ ) are greater than that of the untreated activated carbon. It is speculated that the presence of metal ions i.e., $\mathrm{Ba}^{2+}$ and $\mathrm{Mg}^{2+}$ on activated carbon surface could reduce the desorption energy, thereby enhancing the desorption efficiency.

\subsection{Effect of regeneration}

Table 5 summarizes results of the physico-chemical characteristics and adsorption capacity of the regenerated activated carbon. Upon regeneration, the micropore volume decreases by $5.6 \%$ on $\mathrm{AC}$, increases by $2.6 \%$ on $\mathrm{AC}-\mathrm{Ba}$ and increases by $13 \%$ on $\mathrm{AC}-\mathrm{Mg}$. The density of oxygen functional group of $\mathrm{AC}$ is $269 \mu \mathrm{g} / \mathrm{g}$ (a decrease of $7.2 \%$ ), $327 \mu \mathrm{g} / \mathrm{g}$ of $\mathrm{AC}-\mathrm{Ba}$ (a decrease of $4.7 \%$ ) and 272 $\mu \mathrm{g} / \mathrm{g}$ of $\mathrm{AC}-\mathrm{Mg}$ (a decrease of $11 \%$ ), respectively. When the influent benzene concentration was $2486 \mathrm{ppm}$, the adsorption capacity of the regeneration adsorbents (desorbed at $400^{\circ} \mathrm{C}$ ) were $203 \mathrm{mg} / \mathrm{g}$ (a decrease of $10.2 \%$ ) for $\mathrm{AC}, 178 \mathrm{mg} / \mathrm{g}$ (a decrease of 1.7\%) for AC-Ba, and 193 $\mathrm{mg} / \mathrm{g}$ (an increase of $2.1 \%$ ) for $\mathrm{AC}-\mathrm{Mg}$, respectively. When the influent acetate concentration of was $2352 \mathrm{ppm}$,

Table 4

Length of unused bed (LUB) and length of adsorption wave (Lz) of benzene and acetate adsorption

\begin{tabular}{|c|c|c|c|c|c|c|c|c|c|c|}
\hline & & $\mathrm{AC}$ & $\mathrm{AC}-\mathrm{Ba}$ & $\mathrm{AC}-\mathrm{Mg}$ & $\mathrm{AC}$ & $\mathrm{AC}-\mathrm{Ba}$ & $\mathrm{AC}-\mathrm{Mg}$ & $\mathrm{AC}$ & $\mathrm{AC}-\mathrm{Ba}$ & $\mathrm{AC}-\mathrm{Mg}$ \\
\hline \multirow[t]{3}{*}{ Benzene } & & \multicolumn{3}{|c|}{$2486 \mathrm{ppm}$} & \multicolumn{3}{|c|}{2019 ppm } & \multicolumn{3}{|c|}{$784 \mathrm{ppm}$} \\
\hline & $\operatorname{LUB}(\mathrm{cm})$ & 1.27 & 2.45 & 1.68 & 1.61 & 1.37 & 1.34 & 1.27 & 1.48 & 1.14 \\
\hline & $\mathrm{Lz}(\mathrm{cm})$ & 1.41 & 3.31 & 1.94 & 1.88 & 1.65 & 1.65 & 1.47 & 1.77 & 1.21 \\
\hline \multirow[t]{3}{*}{ Acetate } & & \multicolumn{3}{|c|}{$2352 \mathrm{ppm}$} & \multicolumn{3}{|c|}{$1528 \mathrm{ppm}$} & \multicolumn{3}{|c|}{735 ppm } \\
\hline & LUB(cm) & 2.55 & 2.96 & 2.22 & 3.75 & 2.79 & 3.28 & 1.81 & 1.94 & 1.88 \\
\hline & $\mathrm{Lz}(\mathrm{cm})$ & 3.35 & 3.82 & 3.28 & 6.30 & 4.05 & 4.89 & 2.21 & 2.28 & 2.28 \\
\hline
\end{tabular}



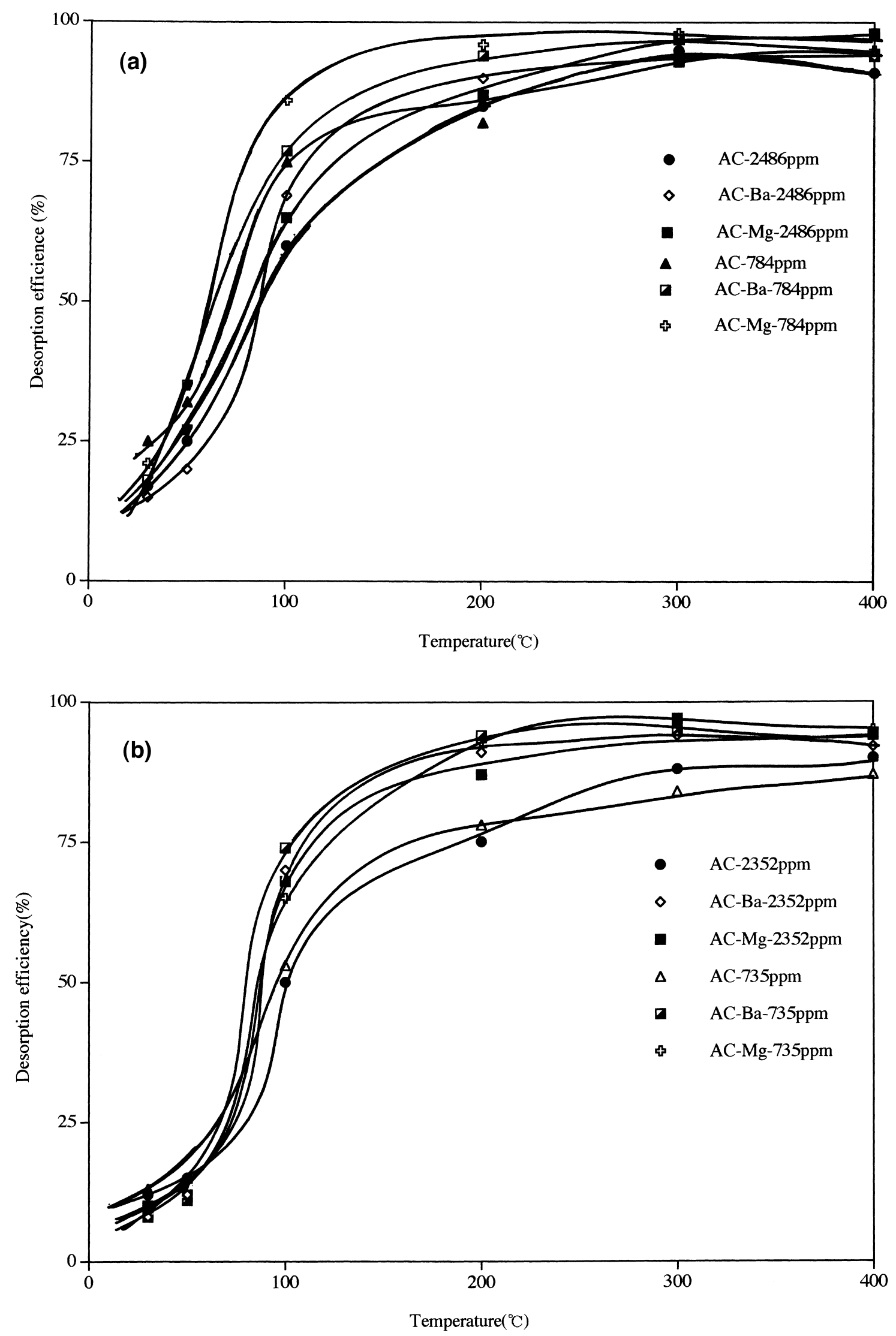

Fig. 4. Desorption efficiency of benzene (a) and acetic acid (b). 
Table 5

Adsorption capacity and physico-chemical characteristics of regenerated adsorbent for benzene and acetate adsorption

\begin{tabular}{llllllll}
\hline $\begin{array}{l}\text { Adsorbent } \\
\text { (regeneration) }\end{array}$ & $\begin{array}{l}\text { Adsorption } \\
\text { capacity of } \\
\text { benzene } \\
(\mathrm{mg} / \mathrm{g})\end{array}$ & $\begin{array}{l}\text { Adsorption } \\
\text { capacity of } \\
\text { acetate } \\
(\mathrm{mg} / \mathrm{g})\end{array}$ & $\begin{array}{l}\text { Micropore } \\
\text { volume } \\
(\mathrm{cc} / \mathrm{g})\end{array}$ & $\begin{array}{l}\text { Hydroxyl } \\
\text { group }(\mathrm{OH}) \\
(\mu \mathrm{eq} / \mathrm{g})\end{array}$ & $\begin{array}{l}\text { Carbonyl } \\
\text { group }(\mathrm{CO}) \\
(\mu \mathrm{eq} / \mathrm{g})\end{array}$ & $\begin{array}{l}\text { Carboxyl } \\
\text { group } \\
(\mathrm{COOH}) \\
(\mu \mathrm{eq} / \mathrm{g})\end{array}$ & $\begin{array}{l}\text { Total } \\
\text { oxygen } \\
\text { functional } \\
\mathrm{Group}(\mu \mathrm{eq} / \mathrm{g})\end{array}$ \\
\hline $\mathrm{AC}$ & $203 \pm 23^{\text {abc }}$ & $298 \pm 12$ & $0.287 \pm 0.021$ & $156 \pm 13$ & $52 \pm 10$ & $61 \pm 4$ & $269 \pm 8$ \\
$\mathrm{AC}-\mathrm{Ba}$ & $178 \pm 14$ & $260 \pm 18$ & $0.275 \pm 0.029$ & $32 \pm 8$ & $120 \pm 8$ & $175 \pm 13$ & $327 \pm 11$ \\
$\mathrm{AC}-\mathrm{Mg}$ & $193 \pm 16$ & $334 \pm 8$ & $0.312 \pm 0.019$ & $106 \pm 5$ & $106 \pm 5$ & $53 \pm 6$ & $272 \pm 6$ \\
\hline
\end{tabular}

${ }^{\mathrm{b}}$ The regeneration temperature is $400^{\circ} \mathrm{C}$ and the influent concentration of benzene and acetate is 2486 and 2352 ppm, respectively.

${ }^{\mathrm{c}}$ Sample number of adsorption capacity is three and the others are five.

${ }^{\mathrm{a}}$ Standard deviation.

the adsorption capacity of the regenerated activated carbon (desorbed at $400^{\circ} \mathrm{C}$ ) is $298 \mathrm{mg} / \mathrm{g}$ (a decrease of $6.3 \%$ ) for $\mathrm{AC}, 260 \mathrm{mg} / \mathrm{g}$ (a decrease of $2.6 \%$ ) for $\mathrm{AC}-\mathrm{Ba}$ and 334 $\mathrm{mg} / \mathrm{g}(\mathrm{an}$ increase of $24.2 \%$ ) for $\mathrm{AC}-\mathrm{Mg}$, respectively. The acetic acid adsorption capacity of the regenerated $\mathrm{AC}-\mathrm{Mg}$ is greatest among all activated carbon samples.

It is speculated that at a desorption temperature of $400^{\circ} \mathrm{C}$ (Note: the melting point of $\mathrm{Mg}\left(\mathrm{NO}_{3}\right)_{2}$ is $330^{\circ} \mathrm{C}$ ) $\mathrm{Mg}\left(\mathrm{NO}_{3}\right)_{2}$ melts. Results indicate that when regenerated at $400^{\circ} \mathrm{C}$, the pore volume increases from 0.276 to 0.312 $\mathrm{cm}^{3} / \mathrm{g}$ (an increase of $13.0 \%$ ) for $\mathrm{AC}-\mathrm{Mg}$, from 0.268 to $0.275 \mathrm{~cm}^{3} / \mathrm{g}$ (a slight increase of $2.6 \%$ ) for AC-Ba and decrease from 0.34 to $0.287 \mathrm{~cm}^{3} / \mathrm{g}$ (a slight decrease of $5.6 \%)$.

At $400^{\circ} \mathrm{C}, \mathrm{Mg}\left(\mathrm{NO}_{3}\right)_{2}$ melts. The liquid $\mathrm{Mg}\left(\mathrm{NO}_{3}\right)_{2}$ cracks open the micropores that are otherwise occupied by the deposited $\operatorname{Mg}\left(\mathrm{NO}_{3}\right)_{2}$ salts. As mentioned above the acetic acid adsorption capacity of the regenerated $\mathrm{AC}-\mathrm{Mg}$ increases by $24.2 \%$. Apparently the $\mathrm{Mg}\left(\mathrm{NO}_{3}\right)_{2}$ provides catalytic advantages for acetic acid adsorption.

\section{Conclusions}

Results clearly indicate that $\mathrm{Ba}\left(\mathrm{NO}_{3}\right)_{2}$ and $\mathrm{Mg}\left(\mathrm{NO}_{3}\right)_{2}$ treatment of the activated carbon can reduce the specific surface area, pore volume and pore diameter. Significant variation of micropore volume distribution between the treated and untreated activated carbon was observed at the pore diameter range of less than $7.0 \AA$. Major oxygen functional groups are hydroxyl for AC, carboxyl for AC$\mathrm{Ba}$ and hydroxyl and carboxyl for $\mathrm{AC}-\mathrm{Mg}$. $\mathrm{Ba}^{2+}$ is a stronger oxidant than $\mathrm{Mg}^{2+}$, therefore it is possible that $\mathrm{Ba}^{2+}$ can oxidize the hydroxyl and carbonyl groups to carboxyl group. The length of unused bed and adsorption zone of acetic acid adsorption is greater than those of benzene. The adsorption energy of acetic acid is smaller than that of benzene due in part to the fact that acetic acid, having methyl and carboxyl functional groups, is polar, and benzene without any functional group, is nonpolar. The acetic acid can be adsorbed onto both the non-polar and the polar sites of adsorbent, whereas the benzene can only be adsorbed onto the non-polar sites.

When regenerated at a temperature of $400^{\circ} \mathrm{C}, \mathrm{AC}-\mathrm{Mg}$ exhibits an acetic acid adsorption capacity greater than that of the untreated AC. Apparently at $400^{\circ} \mathrm{C}, \mathrm{Mg}\left(\mathrm{NO}_{3}\right)_{2}$ melts. Liquid $\mathrm{Mg}\left(\mathrm{NO}_{3}\right)_{2}$ cracks open the micropores and increase the micropore volume and therefore, the surface area. As a result the adsorption capacity of acetic acid increases.

\section{References}

[1] Parkash J, Pirmalakhandan N, Speece RE. Environ Sci Technol 1994;28:1403.

[2] Moretti EC, Mukhopadhhyay N. Chem Eng Progr 1993;89:20.

[3] Ruhl MJ. Chem Eng Progr 1993;89:37.

[4] Ruddy EN, Caroll LA. Chem Eng Progr 1993;89:28.

[5] Ruthven DM, editor, Principles of adsorption \& adsorption process, New York NY: John Wiley, 1984, pp. 239-40.

[6] Dubinin MM. Carbon 1987;25:593.

[7] Dubinin MM, Polyakov NS, Kataebva LI. Carbon 1991;29:481.

[8] Urano K, Omori S, Yamato E. Environ Sci Technol 1982;16:10.

[9] Kinoshita K, editor, Carbon: Electrochemical and physicochemical properties, New York, NY: John Wiley, 1988, pp. 189-90.

[10] Hudson JL, Johnson EH, Natush DFS, Solomon RL. Environ Sci Technol 1974;8:238.

[11] Stoeckli HF, Kraehenbuehl F, Morel D. Carbon 1983;21:589.

[12] Werner DM. Am Ind Hyg Assoc J 1985;46:585.

[13] Ikeda H, Asaba H, Takeuchi Y. J Chem Eng Jpn 1988;21:91.

[14] Hahn CS, Cho HS, Yang HS. Carbon 1981;19:225.

[15] Switatkowski A, Goworek J. Carbon 1987;25:333.

[16] Hatakeyama S, Ohno M, Weng JH, Takagi H, Akimoto H. Environ Sci Technol 1987;21:52.

[17] Wakler Jr. PL, Cariaso OC, Ismail IMK. Carbon 1980;18:375.

[18] Cheremisinoff PN, Ellerbuusch F, editors, Carbon adsorption handbook, Ann Arbor, MI: Luis Science Publishers, 1978, pp. $390-1$. 
[19] McCabe WL, Smith JC, editors, Unit operations of chemical engineering, 3rd ed, New York, NY: McGraw-Hill, 1976, pp. 291-8.
[20] Weber Jr WJ, editor, Physicochemical processes for water quality control, New York, NY: John Wiley, 1972, pp. $175-9$. 